\title{
Improving grain yield and water use efficiency of winter wheat through a combination of manure and chemical nitrogen fertilizer on the Loess plateau, China
}

Haoqing Zhang ${ }^{1,2}$, Xinyang Yu ${ }^{1,2}$, Zhongyu Jin ${ }^{1,2}$, Wei Zheng ${ }^{1,2}$, Bingnian Zhai ${ }^{1,2^{*}}$, Ziyan Li $^{1,2^{*}}$

${ }^{1}$ College of Natural Resources and Environment, Northwest A\&F University, Yangling, Shaanxi 712100, China. ${ }^{2}$ Key Laboratory of Plant Nutrition and the Agro-environment in Northwest China, Ministry of Agriculture, Yangling, Shaanxi 712100,China.*Corresponding authors: zhaibingnian@nwsuaf.edu.cn; liziyan0161@126.com

\begin{abstract}
Developing an effective fertilization management practice is crucial for ensuring food security in dryland. A 3-year field experiment was conducted on the Loess plateau dryland, China, to investigate the effects of manure and nitrogen $(\mathrm{N})$ fertilization on soil water regime, grain yield, and water use efficiency (WUE) of winter wheat (Triticum aestivum). The results showed that soil water content at winter wheat sowing was $13.4 \mathrm{~mm}(3.7 \%)$ higher with manure than without after 2 years of fertilization. Additional manure increased soil water recharge, grain yield, and WUE by a mean of $20.7 \%, 11.6 \%$ and $12.6 \%$, respectively, relative to those without manure. Compared with applying manure alone, $\mathrm{N}$ fertilization improved soil water recharge, grain yield and WUE by a mean of $56.3 \%, 11.5 \%$, and $7.0 \%$, respectively. However, no further increases were observed when the $\mathrm{N}$ rate exceeded 75 or $150 \mathrm{~kg} \mathrm{~N} \mathrm{ha}^{-1}$, and combining $78 \mathrm{~kg} \mathrm{~N} \mathrm{ha}^{-1}$ fertilizer with manure is sufficient to get $95 \%$ of the theoretical highest yield. Therefore, combining manure (30 $\mathrm{t} \mathrm{ha}^{-1}$ poultry or pig manure) with $78-150 \mathrm{~kg} \mathrm{~N}$ $\mathrm{ha}^{-1}$ chemical $\mathrm{N}$ fertilizer (manure- $\mathrm{N}$ : chemical- $\mathrm{N}=1: 0.47-0.91$ ) is recommended for achieving the sustainable winter wheat farming system on the Loess plateau.
\end{abstract}

Keywords: Soil water regime, high-yield and water-efficient fertilization, dryland farming 


\section{Introduction}

Wheat (Triticum aestivum) is a globally major food crop, whose production covers an area of $2.18 \times 108$ ha, accounting for more than $20 \%$ of the world's arable land. China is one of the largest wheat producing countries, with a total planting area of $2.43 \times 107$ ha, of which approximately $27 \%-29 \%$ is located in the Loess plateau dryland (Gao et al., 2009). However, wheat production in this region are facing great challenge of a scant water supply and nutrient deficit. Due to the sparse and deep groundwater resources, rainfall is the sole water source for wheat production in the Loess Plateau, which is limited (200-600 mm) and unevenly distributed. Only $30 \%-40 \%$ of annual rainfall occurs during winter wheat growing season, whereas most of the rain falls between July and September, which is concurrent with the summer fallow between two growing seasons of winter wheat ( $\mathrm{Li}$ et al., 2015). Meanwhile, unreasonable cultivation practices, including excessive chemical fertilizer input and intensive soil cultivation result in soil with a fragile structure, low nutrients availability and water holding capacity (Wu et al., 2004).

Within this context, organic materials input is gaining increasingly attention to sustain soil fertility and promote crop production in the Loess plateau. In 2011, China produced animal manure yielding up to 3 trillion tons, and it will be a huge waste if they are untreated or non-recycled (He et al., 2016). Unlike the long-term application of chemical fertilizer which results in further soil degradation and a series of environmental problems (Ju et al., 2009), animal manure amendment supplies both major and micro nutrients necessary for plant growth. And provides a better environment for root development by improving soil physical, chemical, and biological properties (Pan et al., 2015; Schoebitz and Vidal, 2016), which, in turn, improves nutrient and water uptake by winter wheat. (Foster et al., 2016; Guo et al., 2016; Ibrahim et al., 2015; Shah et al., 2016). More importantly, the ability of manure to improve mean weight diameter of the aggregates, total porosity, water field-saturated hydraulic conductivity, infiltration rate, and water holding capacity of soil conserves more rainfall in the soil profile, reduces evaporation through the soil surface, and improves use of the water available for crop growth (Bandyopadhyay, et al., 2010; Yang et al., 2015). However, using manure alone is insufficient to maintain the present production levels of high yielding varieties of winter wheat (Efthimiadu et al., 2010), as most of the $\mathrm{N}$ in manure is in an organic form, and a long time is needed for mineralization before it is available for plant uptake ( $\mathrm{Li}$ and $\mathrm{Li}, 2014)$. Therefore, an integrated nutrient management, in which both manure and chemical $\mathrm{N}$ fertilizer are used simultaneously, may be a more compatible approach in dryland.

Although emerging evidence indicates that integrated use of manure and chemical $\mathrm{N}$ fertilizer is a feasible approach to improve winter wheat production and water use efficiency (WUE) in the Loess Plateau (Fan et al., 2005a; Fan et al., 2005b; Liu et al., 2013), the problem of blind fertilization still remains in most areas of the Loess Plateau. As there is a lack of systematic and comprehensive observations of the optimal fertilization ratio for manure- $\mathrm{N}$ and chemical-N to achieve a high-yielding, water use efficiency and sustainable winter wheat cropping system. In the present study, we used a three-year long spilt-plot design, stationary field experiment in the Loess plateau, to determine; (1) the responses of soil water content, grain yield and WUE of winter wheat to the combination of manure and different $\mathrm{N}$ application rates. And (2) determine the recommended combined ratio of manure- $\mathrm{N}$ and chemical-N for sustainable winter wheat production systems under dryland condition. 


\section{Materials and Methods}

\subsection{Site description}

A 3-year stationary winter wheat monoculture experiment was conducted from October 2011 to June 2014 in Bai Shui $\left(109^{\circ} 58^{\prime} \mathrm{N} 35^{\circ} 18^{\prime} \mathrm{E}, 850 \mathrm{~m}\right.$ asl) Shaanxi Province, China. Bai Shui county is located in the north of the Loess plateau and has a temperate continental monsoon climate, with mean annual temperature of $11.4^{\circ} \mathrm{C}$ and annual precipitation of 577.8 $\mathrm{mm}$. Agricultural production in this area is completely dependent on natural precipitation. Data of monthly rainfall during the experimental years was obtained from the Bai Shui county Meterological Station (Figure 1).

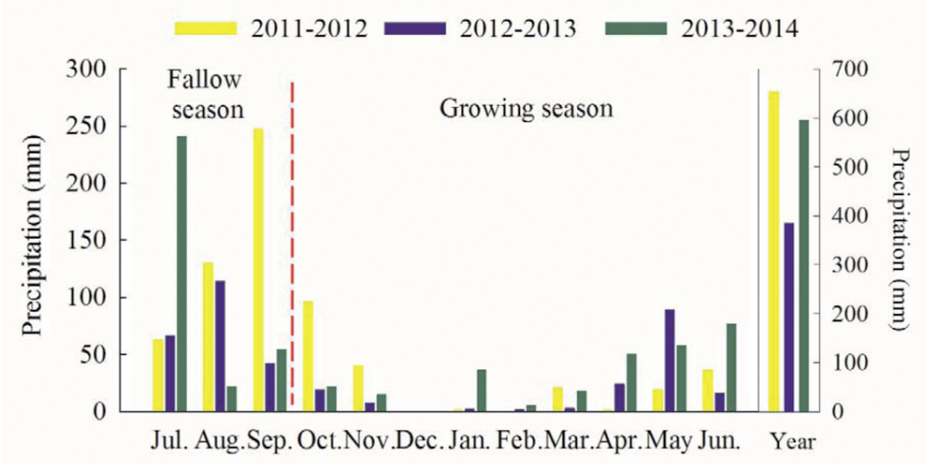

Figure 1. Monthly and yearly precipitation at the experimental site over the 3 year experiment

The experimental field had been used for winter wheat production for a long time prior to this experiment. The soil at the experimental site is classified as Calcic Cambisols (FAO taxonomy), with mean bulk density of $\sim 1.30 \mathrm{~g} \mathrm{~cm}^{-3}$ in $0-200 \mathrm{~cm}$ soil layer. The background soil sample collected from 0-20 $\mathrm{cm}$ layer at the experimental site had $12.4 \mathrm{~g} \mathrm{~kg}^{-1}$ organic matter, $0.8 \mathrm{~g} \mathrm{~kg}^{-1}$ total N, $9.2 \mathrm{mg} \mathrm{kg}^{-1}$ Olsen-P, $177.2 \mathrm{mg} \mathrm{kg}^{-1}$ available K, $76.55 \%$ sand concentration, $19.60 \%$ silt concentration, and $3.85 \%$ clay concentration. All the basic soil properties were measured with the methods described by Bao (2000).

\subsection{Experimental design}

The experiment was carried out with two treatment factors: (1) with and without manure, and (2) five $\mathrm{N}$ application rates of $0,75,150,225$, and $300 \mathrm{~kg} \mathrm{~N}$ $\mathrm{ha}^{-1}$. The 10 treatments were arranged in a split-plot design with four replications each; the five $\mathrm{N}$ fertilizer application rates were in the main plot, and manure treatments (with and without manure) were subplots. Plot size was 6-m wide and 10-m long, and all treatments were arranged randomly.

A widely used local winter wheat cultivar called 'Jinmai-47' was used as the test crop, and was sown on 12, 15 and 17 October in 2011, 2012, and 2013 , respectively by a seeding machine, at a rate of $150 \mathrm{~kg} \mathrm{ha}^{-1}$, with $20 \mathrm{~cm}$ wide rows and a sowing depth of $5 \mathrm{~cm}$. On the same day right before winter wheat seeding, fertilizer was applied to the field. The manure areas were fertilized with a combination of manure and the five different application rates of $\mathrm{N}$ fertilizer. 
The areas without manure were only fertilized with chemical $\mathrm{N}$ fertilizer, at the application rate of 0,75 , 150,225 and $300 \mathrm{~kg} \mathrm{~N} \mathrm{ha}^{-1}$ in each plot, respectively. In addition, $90 \mathrm{~kg} \mathrm{P}_{2} \mathrm{O}_{5} \mathrm{ha}^{-1}$ and $60 \mathrm{~kg} \mathrm{~K}_{2} \mathrm{O}$ ha $^{-1}$ were applied to all plots. The manure was applied as pig manure. Well-composted pig manure were collected from hoggery, and spread by a shovel at $30 \mathrm{Mg} \mathrm{ha}^{-1}$ on fresh weight basis (the water and nutrient contents of the manures applied in the study are shown in Table 1).
The $\mathrm{N}$ fertilizer was applied as urea $(\mathrm{N}: 46 \%), 70 \%$ of which was applied at sowing, and $30 \%$ was applied at the elongation stage of winter wheat (early April). The phosphorus (P) fertilizer was superphosphate $\left(\mathrm{P}_{2} \mathrm{O}_{5}: 16 \%\right)$, and the potassium $(\mathrm{K})$ fertilizer was a sulfate of potash $\left(\mathrm{K}_{2} \mathrm{O}: 50 \%\right)$. All fertilizers were applied evenly and incorporated into the top $0-20 \mathrm{~cm}$ soil layer before seeding.

Table 1. Water and nutrients contents of manures applied during the experimental years.

\begin{tabular}{cccccccc}
\hline \multirow{2}{*}{ Year } & $\begin{array}{c}\text { Water content } \\
(\%)\end{array}$ & $\begin{array}{c}\mathrm{pH} \text { Organic C } \\
\left(\mathrm{g} \mathrm{kg}^{-1}\right)\end{array}$ & $\begin{array}{c}\mathrm{N} \text { content } \\
\left(\mathrm{g} \mathrm{kg}^{-1}\right)\end{array}$ & $\begin{array}{c}\text { P content } \mathrm{K} \text { content } \\
\left(\mathrm{g} \mathrm{kg}^{-1}\right)\end{array}$ & $\begin{array}{c}\left(\mathrm{g} \mathrm{kg}^{-1}\right) \\
\text { C:N ratio }\end{array}$ \\
\hline $2011-2012$ & 22.6 & 7.6 & 107.9 & 7.0 & 10.5 & 12.6 & $15: 1$ \\
$2012-2013$ & 23.1 & 7.6 & 103.8 & 7.5 & 11.1 & 11.8 & $13: 1$ \\
$2013-2014$ & 23.3 & 7.5 & 104.4 & 6.9 & 10.2 & 12.9 & $14: 1$ \\
\hline
\end{tabular}

The wheat was harvested in early June of the following year. All plots were tilled twice, one week after harvest and two weeks before sowing. No supplemental irrigation was provided. Herbicide was used in the blooming stage (early May) of winter wheat every year to control weeds.

\subsection{Sampling and sample analysis}

\subsubsection{Soil sampling}

Before the experiment, soil from 7 random cores at a depth of 0-200 cm layer was collected using an auger (inner diameter, $4.0 \mathrm{~cm}$ ) at an interval of 20 $\mathrm{cm}$, and the soil from the same layer was mixed as a soil sample for background soil moisture determination. Besides, soil collected from $0-20 \mathrm{~cm}$ soil was used for determining the background soil properties. During the experiment, every year at the sowing and harvest time of winter wheat, three soil core samples at depths of $0-200 \mathrm{~cm}$ in each plot were also collected randomly to determine the soil water content. The soil in each $20 \mathrm{~cm}$ layer over the $0-200 \mathrm{~cm}$ depth was separated, and soil from the same layer was mixed and sealed immediately in plastic bags.

The fresh soil samples were brought to the laboratory and dried in an oven at $105^{\circ} \mathrm{C}$ for 12 hours.

The soil bulk density at the depth of 0-200 cm was measured every year before seeding using the cutting ring method (Bao, 2000).

\subsubsection{Plant sampling}

The winter wheat was harvested manually at maturity from each plot in early June of all study years. An area of $12 \mathrm{~m}^{2}$ gathered from three randomly collected quadrats was harvested from every single plot. These wheat samples were dried at $95{ }^{\circ} \mathrm{C}$ for $0.5 \mathrm{~h}$ and at $65{ }^{\circ} \mathrm{C}$ for $24 \mathrm{~h}$ until a constant weight 
was achieved. Grain yield was determined by weighing the dried grain after manual threshing.

\subsection{Calculation methods and data analysis}

Soil water storage $(\mathrm{mm})$ was calculated as:

$W=\sum_{i}^{n} \rho_{i} \times w_{i} \times h_{i} \times 10 / 100$

Where $\rho_{i}\left(\mathrm{~g} \mathrm{~cm}^{-3}\right)$ is soil bulk density; $w_{i} \quad(\%)$ is soil gravimetric water content; $h_{i} \quad(\mathrm{~cm})$ is soil layer depth; is the number of soil layer; $i=20,40$, $60,80 \ldots 200 \mathrm{~cm}$.

Soil water depletion ( $S W D, \mathrm{~mm}$ ) during the growing season was calculated as the difference in soil water storage in the $0-200 \mathrm{~cm}$ layer from winter wheat sowing to harvest. Soil water recharge $(S W R, \mathrm{~mm})$ during the fallow season was calculated as the difference in soil water storage from the beginning to the end of the fallow period at depth of 0-200 cm.

Evapotranspiration $(E T, \mathrm{~mm})$ during growing season of winter wheat was determined by:

$E T=S W D 1 P G 1 I \quad D 1 W g \quad R$

Where $S W D(\mathrm{~mm})$ is the soil water depletion, $P G(\mathrm{~mm})$ the amount of precipitation $(\mathrm{mm})$ during growing season of winter wheat, $I$ the amount of irrigation $(\mathrm{mm}), D$ the soil water drainage $(\mathrm{mm})$, $W g$ the water use by crop through capillary rise from underground water ( $\mathrm{mm})$, and $R$ the surface runoff. The $I$ and $R$ should be ignored since there is no irrigation and runoff in the flat study field. Besides, the $D$ and $W g$ are considered negligible because the extreme high rainfall is infrequent in the region, and the underground water in the Loess Plateau is usually too low to use by the crop. Therefore, the $I, D, W g$ and $R$ are not considered in the present study.

The water use efficiency (WUE, $\mathrm{kg} \mathrm{ha}^{-1} \mathrm{~mm}^{-1}$ ) was calculated as:

$W I I R=Y / E T$

Where $Y\left(\mathrm{~kg} \mathrm{ha}^{-1}\right)$ is the grain yield, and $E T(\mathrm{~mm})$ is the evapotranspiration of winter wheat.

Analysis of variance (ANOVA) was conducted to detect differences using SPSS 19.0 for Windows (SPSS Inc., Chicago, IL, USA). A two-way ANOVA was performed to test the manure, the $\mathrm{N}$ application rates, and their interactive effects on all data for each experimental year (Table 2). In addition, a one-way ANOVA was used to test for differences between $\mathrm{N}$ application rates in the groups with and without manure. Comparisons of means between the groups with and without manure, and the different $\mathrm{N}$ application rates were performed using Duncan's test. Parabolic regression was used to fit the data between $\mathrm{N}$ rate and grain yield of winter wheat. A correlation coefficient, $r$, analysis was also performed. All p-values $<0.05$ were considered significant. 
Table 2. Analysis of variance of the effects of nitrogen $(\mathrm{N})$ fertilizer rate, manure and their interactions with soil water storage (SWS) at winter wheat sowing and harvest, soil water depletion (SWD) during growing season, soil water recharge (SWR) during fallow season, evapotranspiration (ET), grain yield, and water use efficiency (WUE) of winter wheat (P-values).

\begin{tabular}{|c|c|c|c|c|c|c|c|c|}
\hline Year & Sources & $\begin{array}{c}\text { SWS } \\
\text { (sowing) }\end{array}$ & $\begin{array}{c}\text { SWS } \\
\text { (harvest) }\end{array}$ & SWD & SWR & ET & Grain yield & WUE \\
\hline \multirow[t]{3}{*}{ 2011-2012 } & $\mathrm{N}$ rate $(\mathrm{N})$ & - & 0.002 & 0.002 & - & 0.002 & $<0.001$ & 0.006 \\
\hline & Manure (M) & - & 0.047 & 0.047 & - & 0.047 & $<0.001$ & ns \\
\hline & $\mathrm{N} \times \mathrm{M}$ & - & ns & ns & - & ns & ns & ns \\
\hline \multirow[t]{3}{*}{ 2012-2013 } & $\mathrm{N}$ rate $(\mathrm{N})$ & ns & 0.024 & 0.034 & 0.042 & 0.034 & 0.042 & 0.023 \\
\hline & Manure (M) & ns & ns & ns & 0.036 & ns & $<0.001$ & $<0.001$ \\
\hline & $\mathrm{N} \times \mathrm{M}$ & ns & ns & ns & ns & ns & ns & ns \\
\hline \multirow[t]{3}{*}{ 2013-2014 } & $\mathrm{N}$ rate $(\mathrm{N})$ & ns & ns & 0.006 & 0.033 & 0.006 & $<0.001$ & 0.025 \\
\hline & Manure (M) & 0.005 & ns & ns & 0.018 & ns & $<0.001$ & $<0.001$ \\
\hline & $\mathrm{N} \times \mathrm{M}$ & ns & ns & ns & ns & ns & ns & ns \\
\hline
\end{tabular}

ns, no significant difference at the $5 \%$ level. SWD, difference in soil water storage in the 0-200 cm layer from winter wheat sowing to harvest; SWR, difference between soil water storage in the 0-200 cm layer from the beginning to the end of summer fallow season.

\section{Results}

\subsection{Soil water storage in the $0-200 \mathrm{~cm}$ soil layer}

Adding manure increased soil water storage by $3.7 \%$ compared with the treatment without manure at the sowing time during the 2013-2014 season $(\mathrm{P}<0.05$, Table 3). No differences were noted in soil water storage between $\mathrm{N}$ application rates at winter wheat sowing throughout the experimental years. After winter wheat harvest, manure amendment decreased $(\mathrm{P}<0.05)$ soil water by a mean of $8.4 \%$ compared with no manure during 2011-2012, but this decrease did not continue during the next two years. Relative to applying manure alone, additional chemical $\mathrm{N}$ input of 75, 150, and $225 \mathrm{~kg} \mathrm{~N} \mathrm{ha}^{-1}$ decreased $(\mathrm{P}<0.05)$ soil water storage by $15.6 \%, 16.7 \%$, and $18.2 \%$, respectively in 2011-2012, and the input of $225 \mathrm{~kg} \mathrm{~N} \mathrm{ha}^{-1}$ chemical $\mathrm{N}$ decreased soil water storage by $6.7 \%$ in 2012-2013 after winter wheat harvest. Manure and N rate had no significant effect on soil water storage after harvest in 2013-2014, probably due to the higher rainfall during the growing season of that year.

\subsection{Soil water depletion and recharge}

According to Table 4, although the average soil water depletion was greater $(6.3 \%)$ for manure treatments than that for no manure treatments during the winter wheat growing season in 2011-2012 $(\mathrm{P}<0.05)$, no differences were observed between the manure and no-manure groups in the next two years. Compared with applying manure alone, chemical $\mathrm{N}$ input levels from 75 to $225 \mathrm{~kg} \mathrm{~N} \mathrm{ha}^{-1}, 150$ to 225 $\mathrm{kg} \mathrm{N} \mathrm{ha}^{-1}$, and 150 to $300 \mathrm{~kg} \mathrm{~N} \mathrm{ha}^{-1}$ increased soil water depletion by $12.6 \%-14.7 \%, 55.9 \%-56.2 \%$ and $10.1 \%-18.2 \%$ during the winter wheat growing season in 2011-2012, 2012-2013 and 2013-2014, respectively $(\mathrm{P}<0.05)$. 
Table 3. Soil water storage ( $\mathrm{mm}$ ) in the $0-200 \mathrm{~cm}$ layer at sowing and harvest during the 3-year experiment.

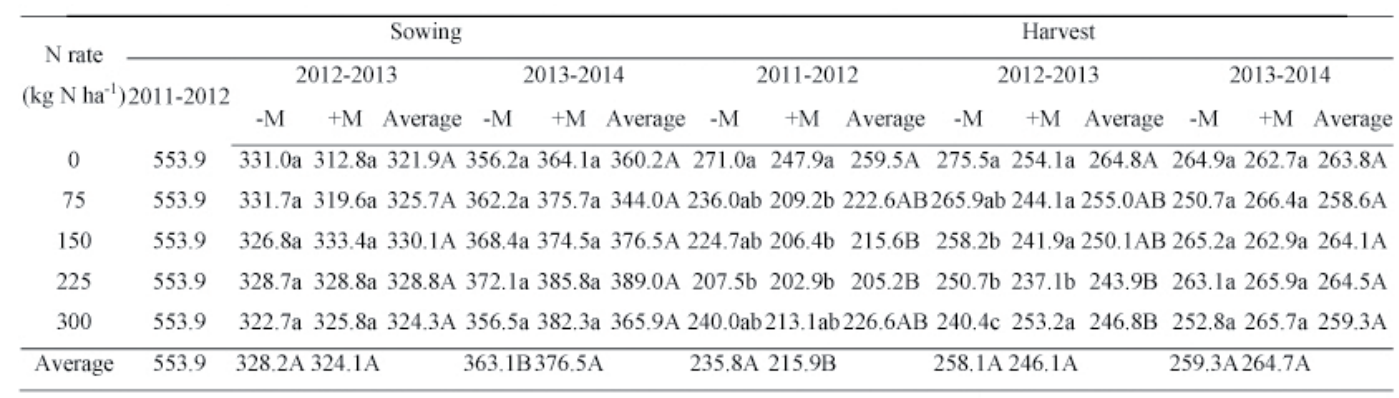

Different lowercase (one-way ANOVA) and uppercase (two-way ANOVA) letters denote significant differences between treatments at the $5 \%$ level. $-\mathrm{M}$, treatments without manure; $+\mathrm{M}$, treatments with manure.

Table 4. Soil water depletion $(\mathrm{mm})$ in the $0-200 \mathrm{~cm}$ layer during the winter wheat growing season.

\begin{tabular}{cccccccccc}
\hline $\begin{array}{c}\text { N rate } \\
\left(\mathrm{kg} \mathrm{N} \mathrm{ha}^{-1}\right)\end{array}$ & \multicolumn{3}{c}{$2011-2012$} & \multicolumn{3}{c}{$2012-2013$} & \multicolumn{3}{c}{$2013-2014$} \\
\hline 0 & $282.9 \mathrm{~b}$ & $306.0 \mathrm{~b}$ & $294.5 \mathrm{~B}$ & $55.5 \mathrm{~b}$ & $58.7 \mathrm{~b}$ & $57.1 \mathrm{~B}$ & $91.3 \mathrm{~b}$ & $101.4 \mathrm{~b}$ & $96.4 \mathrm{~B}$ \\
75 & $317.9 \mathrm{ab}$ & $344.7 \mathrm{a}$ & $331.3 \mathrm{AB}$ & $65.8 \mathrm{ab}$ & $75.5 \mathrm{ab}$ & $70.7 \mathrm{AB}$ & $111.5 \mathrm{a}$ & $109.3 \mathrm{ab}$ & $110.4 \mathrm{AB}$ \\
150 & $329.2 \mathrm{ab}$ & $347.5 \mathrm{a}$ & $338.4 \mathrm{~A}$ & $68.6 \mathrm{ab}$ & $91.5 \mathrm{a}$ & $80.1 \mathrm{~A}$ & $103.2 \mathrm{ab}$ & $111.6 \mathrm{a}$ & $107.4 \mathrm{AB}$ \\
225 & $346.4 \mathrm{a}$ & $351.0 \mathrm{a}$ & $348.7 \mathrm{~A}$ & $78.0 \mathrm{ab}$ & $91.7 \mathrm{a}$ & $84.9 \mathrm{~A}$ & $109.0 \mathrm{ab}$ & $119.9 \mathrm{a}$ & $114.5 \mathrm{~A}$ \\
300 & $313.9 \mathrm{ab}$ & $340.8 \mathrm{ab}$ & $327.4 \mathrm{~B}$ & $82.3 \mathrm{a}$ & $72.6 \mathrm{ab}$ & $77.5 \mathrm{AB}$ & $103.7 \mathrm{ab}$ & $116.6 \mathrm{a}$ & $110.2 \mathrm{AB}$ \\
\hline Average & $318.1 \mathrm{~B}$ & $338.0 \mathrm{~A}$ & & $70.0 \mathrm{~A}$ & $78.0 \mathrm{~A}$ & & $103.7 \mathrm{~A}$ & $111.8 \mathrm{~A}$ & \\
\hline
\end{tabular}

Different lowercase (one-way ANOVA) and uppercase (two-way ANOVA) letters denote significant differences between treatments at the $5 \%$ level. $-\mathrm{M}$, treatments without manure; $+\mathrm{M}$, treatments with manure. Soil water depletion was calculated as the difference in soil water storage in the $0-200 \mathrm{~cm}$ layer from winter wheat sowing to harvest.

Since the field experiment was initiated in October 2011, values of rainfall harvest during summer fallow were only observed in the 2012-2013 and 20132014 season (Table 5). Mean soil water recharge in the manure group increased by $17.2 \%$ during the summer fallow period in $2012-2013$ and by $24.2 \%$ in 2013-2014 compared to that in the no-manure treatment $(\mathrm{P}<0.05)$. Chemical $\mathrm{N}$ fertilization tended to improve soil water storage during the fallow season as well. Compared with applying manure alone, soil water recharge increased with $\mathrm{N}$ rate from 150 to $225 \mathrm{~kg} \mathrm{~N}$ ha-1 $^{-1}$ by $94.0 \%-95.7 \%$ in $2012-2013$ and from 150 to $300 \mathrm{~kg} \mathrm{~N}$ ha $^{-1}$ by $19.6 \%-35.2 \%$ in $2013-$ $2014(\mathrm{P}<0.05)$. 
Table 5. Soil water recharge ( $\mathrm{mm}$ ) in the 0-200 cm layer during the fallow periods in 2012-2013 and 2013-2014.

\begin{tabular}{|c|c|c|c|c|c|c|}
\hline \multirow{2}{*}{$\begin{array}{c}\text { N rate } \\
\left(\mathrm{kg} \mathrm{N} \mathrm{ha}^{-1}\right)\end{array}$} & \multicolumn{3}{|c|}{$2012-2013$} & \multicolumn{3}{|c|}{ 2013-2014 } \\
\hline & $-M$ & $+\mathrm{M}$ & Average & $-M$ & $+\mathrm{M}$ & Average \\
\hline 0 & $60.0 \mathrm{c}$ & $64.9 b$ & $62.5 \mathrm{~B}$ & $80.7 \mathrm{~b}$ & $110.0 \mathrm{~b}$ & $95.4 \mathrm{~B}$ \\
\hline 75 & $95.7 b$ & $\begin{array}{c}110.4 \mathrm{a} \\
\mathrm{b}\end{array}$ & $103.1 \mathrm{AB}$ & $96.3 \mathrm{ab}$ & $131.6 \mathrm{a}$ & $114.0 \mathrm{AB}$ \\
\hline 150 & $\begin{array}{c}102.1 \mathrm{a} \\
\mathrm{b}\end{array}$ & $127.0 \mathrm{a}$ & $114.6 \mathrm{~A}$ & $110.2 \mathrm{a}$ & $132.6 \mathrm{a}$ & $121.4 \mathrm{~A}$ \\
\hline 225 & $121.2 \mathrm{a}$ & $125.9 \mathrm{a}$ & $123.6 \mathrm{~A}$ & $121.4 \mathrm{a}$ & $148.7 \mathrm{a}$ & $135.1 \mathrm{~A}$ \\
\hline 300 & $82.7 b c$ & $\begin{array}{c}112.7 \mathrm{a} \\
\mathrm{b}\end{array}$ & $97.7 \mathrm{AB}$ & $116.1 \mathrm{a}$ & $129.1 \mathrm{ab}$ & $122.6 \mathrm{~A}$ \\
\hline Average & $92.3 \mathrm{~B}$ & $108.2 \mathrm{~A}$ & & 105.0B & $130.4 \mathrm{~A}$ & \\
\hline
\end{tabular}

Different lowercase (one-way ANOVA) and uppercase (two-way ANOVA) letters denote significant differences between treatments at the $5 \%$ level. $-\mathrm{M}$, treatments without manure; $+\mathrm{M}$, treatments with manure. Soil water recharge was calculated as the difference between soil water storage at the previous year's winter wheat harvest and soil water storage at wheat sowing in the $0-200 \mathrm{~cm}$ layer.

\subsection{ET, grain yield, and WUE of winter wheat}

In comparison with the no-manure group, manure group only improved ET significantly during 2011-
2012, whereas chemical $\mathrm{N}$ fertilization, at the input level of 150 or/and $225 \mathrm{~kg} \mathrm{~N}^{-1} \mathrm{a}^{-1}$ improved ET significantly throughout the experimental years $(\mathrm{P}<0.05$, Table 6)

Table 6. Evapotranspiration (ET), grain yield, and water use efficiency (WUE) of winter wheat during the 3-year experiment.

\begin{tabular}{|c|c|c|c|c|c|c|c|c|c|c|}
\hline \multirow[t]{2}{*}{ Year } & \multirow{2}{*}{$\begin{array}{c}\text { N rate } \\
\left(\mathrm{kg} \mathrm{N} \mathrm{ha}^{-1}\right)\end{array}$} & \multicolumn{3}{|c|}{$\begin{array}{c}\text { ET } \\
(\mathrm{mm})\end{array}$} & \multicolumn{3}{|c|}{$\begin{array}{l}\text { Grain yield } \\
\left(\mathrm{kg} \mathrm{ha}^{-1}\right)\end{array}$} & \multicolumn{3}{|c|}{$\begin{array}{c}\text { WUE } \\
\left(\mathrm{kg} \mathrm{ha}^{-1} \mathrm{~mm}^{-1}\right)\end{array}$} \\
\hline & & $-\mathrm{M}$ & $+\mathrm{M}$ & Average & $-\mathrm{M}$ & $+\mathrm{M}$ & Average & $-M$ & $+\mathrm{M}$ & Average \\
\hline \multirow{5}{*}{$2011-2012$} & 0 & $497.9 b$ & $521.0 \mathrm{~b}$ & $509.5 \mathrm{~B}$ & $5156 \mathrm{c}$ & $5456 c$ & $5306 \mathrm{C}$ & $10.4 b$ & $10.5 b$ & $10.4 \mathrm{~B}$ \\
\hline & 75 & $532.9 \mathrm{ab}$ & $559.7 \mathrm{a}$ & $546.3 \mathrm{AB}$ & $5722 b$ & $6004 b$ & $5863 \mathrm{~B}$ & $10.7 \mathrm{~b}$ & $10.7 \mathrm{~b}$ & $10.7 \mathrm{~B}$ \\
\hline & 150 & $544.2 \mathrm{ab}$ & $562.5 \mathrm{a}$ & $553.4 \mathrm{~A}$ & $6300 a$ & $6525 \mathrm{a}$ & $6413 \mathrm{~A}$ & $11.6 \mathrm{a}$ & $11.6 \mathrm{a}$ & $11.6 \mathrm{~A}$ \\
\hline & 225 & $561.4 \mathrm{a}$ & $566.0 \mathrm{a}$ & $563.7 \mathrm{~A}$ & $6267 a$ & $6445 \mathrm{a}$ & $6356 \mathrm{~A}$ & $11.2 \mathrm{a}$ & $11.4 \mathrm{a}$ & $11.3 \mathrm{~A}$ \\
\hline & 300 & $528.9 \mathrm{ab}$ & $555.8 \mathrm{a}$ & $542.4 \mathrm{AB}$ & $5656 \mathrm{~b}$ & $5750 \mathrm{~b}$ & $5703 \mathrm{~B}$ & $10.7 \mathrm{~b}$ & $10.3 \mathrm{~b}$ & $10.5 \mathrm{~B}$ \\
\hline \multirow[t]{2}{*}{ Average } & & $533.1 \mathrm{~B}$ & $553.0 \mathrm{~A}$ & & $5820 \mathrm{~B}$ & $6016 \mathrm{~A}$ & & $10.9 \mathrm{~A}$ & $10.9 \mathrm{~A}$ & \\
\hline & 0 & $217.5 b$ & $220.7 b$ & $219.1 \mathrm{~B}$ & $1906 \mathrm{~b}$ & $2414 a$ & $2160 \mathrm{~B}$ & $8.8 \mathrm{~b}$ & $10.0 \mathrm{~b}$ & $9.9 \mathrm{~B}$ \\
\hline \multirow{4}{*}{$2012-2013$} & 75 & $227.8 \mathrm{ab}$ & $237.5 \mathrm{ab}$ & $232.7 \mathrm{AB}$ & $2147 \mathrm{a}$ & $2684 \mathrm{a}$ & $2416 \mathrm{~A}$ & $9.4 \mathrm{~b}$ & $11.3 \mathrm{a}$ & $10.4 \mathrm{AB}$ \\
\hline & 150 & $230.6 \mathrm{ab}$ & $253.5 \mathrm{a}$ & $242.1 \mathrm{~A}$ & $2204 a$ & $2760 \mathrm{a}$ & $2482 \mathrm{~A}$ & $9.6 \mathrm{a}$ & $10.9 \mathrm{ab}$ & $10.2 \mathrm{AB}$ \\
\hline & 225 & $240.0 \mathrm{a}$ & $253.7 \mathrm{a}$ & $246.9 \mathrm{~A}$ & $2432 a$ & $2854 a$ & $2643 \mathrm{~A}$ & $10.1 \mathrm{a}$ & $11.2 \mathrm{a}$ & $10.7 \mathrm{~A}$ \\
\hline & 300 & $244.3 \mathrm{a}$ & $234.6 \mathrm{ab}$ & $239.5 \mathrm{AB}$ & $2389 a$ & $2595 \mathrm{a}$ & $2492 \mathrm{~A}$ & $9.8 \mathrm{a}$ & $11.1 \mathrm{ab}$ & $10.4 \mathrm{AB}$ \\
\hline \multirow[t]{3}{*}{ Average } & & $232.0 \mathrm{~A}$ & $240.0 \mathrm{~A}$ & & $2216 \mathrm{~B}$ & $2661 \mathrm{~A}$ & & $9.5 \mathrm{~B}$ & $11.1 \mathrm{~A}$ & \\
\hline & 0 & $371.3 b$ & $381.4 \mathrm{~b}$ & $376.4 \mathrm{~B}$ & $3705 \mathrm{c}$ & $4345 b$ & $4025 \mathrm{~B}$ & $10.0 \mathrm{~b}$ & $11.4 \mathrm{~b}$ & $10.7 \mathrm{~B}$ \\
\hline & 75 & $391.5 \mathrm{a}$ & $389.3 \mathrm{ab}$ & $390.4 \mathrm{AB}$ & $4064 b c$ & $4510 \mathrm{ab}$ & $4287 \mathrm{AB}$ & $10.4 \mathrm{~b}$ & $11.6 \mathrm{~b}$ & $11.1 \mathrm{~B}$ \\
\hline \multirow[t]{3}{*}{ 2013-2014 } & 150 & $383.2 \mathrm{ab}$ & $391.6 \mathrm{a}$ & $387.4 \mathrm{AB}$ & $4359 \mathrm{ab}$ & $4895 a$ & $4677 \mathrm{~A}$ & $11.4 \mathrm{a}$ & $12.5 \mathrm{a}$ & $12.1 \mathrm{~A}$ \\
\hline & 225 & $389.0 \mathrm{ab}$ & $399.9 \mathrm{a}$ & $394.5 \mathrm{~A}$ & $4520 \mathrm{a}$ & $4979 a$ & $4750 \mathrm{~A}$ & $11.6 \mathrm{a}$ & $12.5 \mathrm{a}$ & $12.0 \mathrm{~A}$ \\
\hline & 300 & $383.7 \mathrm{ab}$ & $396.6 \mathrm{a}$ & $390.2 \mathrm{AB}$ & $4192 \mathrm{bc}$ & 4464ab & $4328 \mathrm{AB}$ & $10.9 \mathrm{ab}$ & $11.3 \mathrm{~b}$ & $11.0 \mathrm{~B}$ \\
\hline Average & & $383.7 \mathrm{~A}$ & $391.8 \mathrm{~A}$ & & $4168 \mathrm{~B}$ & $4639 \mathrm{~A}$ & & $10.9 \mathrm{~B}$ & $11.8 \mathrm{~A}$ & \\
\hline
\end{tabular}

Different lowercase (one-way ANOVA) and uppercase (two-way ANOVA) letters denote significant differences between treatments at the $5 \%$ level. $-\mathrm{M}$, treatments without manure; $+\mathrm{M}$, treatments with manure. 
The grain yield of winter wheat improved by $3.3 \%$, $20.1 \%$ and $3.3 \%$ by manure addition relative to nomanure treatments (Table 6). Compared with applying manure alone, additional chemical $\mathrm{N}$ fertilizer input improved grain yield by $10 \%, 19.6 \%, 18.1 \%$, $5.4 \%$ at the rate of $75,150,225$, and $300 \mathrm{~kg} \mathrm{~N} \mathrm{ha}^{-1}$, respectively in $2011-2012$, and by $12.7 \%$ and $18.0 \%$ at the $\mathrm{N}$ rate of 150 and $225 \mathrm{~kg} \mathrm{~N} \mathrm{ha}^{-1}$, respectively in 2013-2014 $(\mathrm{P}<0.05)$. But it should be noticed that once $\mathrm{N}$ rate was $>150 \mathrm{~kg} \mathrm{~N} \mathrm{ha}^{-1}$, increasing the $\mathrm{N}$ fertilizer rate did not further increase grain yield in most cases. No differences were observed between $\mathrm{N}$ application rates of 75-300 $\mathrm{kg} \mathrm{N}^{-1}$ because of severe water deficit during the growing season in 2012-2013.

Manure amendment had no significant effect on WUE in 2011-2012, but improved WUE by means of $16.8 \%$ and $8.3 \%$ compared to that in the no-manure group in 2012-2013 and 2013-2014, respectively $(\mathrm{P}<0.05)$. The highest WUE was observed when manure was combined with $150 \mathrm{~kg} \mathrm{~N}$ ha-1 $^{-1}$ fertilizer, which was $11.5 \%$ and $25.0 \%$ higher than that in no-fertilized treatment, respectively in 2011-2012 and 2013-2014. In 2012-2013, the combination of manure with $75 \mathrm{~kg}$ $\mathrm{N} \mathrm{ha}^{-1} \mathrm{~N}$ fertilizer produced the highest WUE, which was $28.4 \%$ higher than that in no-fertilized treatment.

\subsection{The correlation between $N$ rate and grain yield of winter wheat}

The grain yield of winter wheat varied as a polynomial function with $\mathrm{N}$ rate under manure conditions (Table 7). To determine the optimal combined ratio of chemical-N and manure- $\mathrm{N}$, we calculated the $\mathrm{N}$ rates corresponding to $95 \%$ of the maximum yield values under manure condition, from the perspective of producing more crop yield with less fertilizer input. The $95 \%$ highest grain yield was $4534 \mathrm{~kg} \mathrm{ha}^{-1}$, corresponding to $\mathrm{N}$ rate of $78 \mathrm{~kg} \mathrm{~N} \mathrm{ha}^{-1}$ on average throughout the experimental years, indicating the combination of manure with $78 \mathrm{~kg} \mathrm{~N}^{-1}$ (manure- $\mathrm{N}$ : fertilizer-N $=1: 0.47$ ) was the most efficient way to achieve high yields in dryland winter wheat cropping system.

Table 7. Optimal $\mathrm{N}$ rates and corresponding highest grain yields.

\begin{tabular}{|c|c|c|c|c|c|}
\hline \multirow[b]{2}{*}{ Year } & \multicolumn{3}{|c|}{ Correlation between $\mathrm{N}$ rates and grain yield } & \multirow{2}{*}{$\begin{array}{c}\text { The } 95 \% \\
\text { highest grain } \\
\text { yield } \\
\left.(\mathrm{kg} \mathrm{ha})^{-1}\right)\end{array}$} & \multirow{2}{*}{\begin{tabular}{|c} 
The \\
corresponding \\
$\mathrm{N}$ rate \\
$\left(\mathrm{kg} \mathrm{N} \mathrm{ha}^{-1}\right)$
\end{tabular}} \\
\hline & Regression equation & $\mathrm{R}^{2}$ & $\begin{array}{l}P \text { value } \\
(n=20)\end{array}$ & & \\
\hline $2011-2012$ & $=-0.039 x^{2}+13.13 x+5389$ & 0.77 & $<0.001$ & 6169 & 78 \\
\hline $2012-2013$ & $=-0.022 x^{2}+8.01 x+2206$ & 0.60 & 0.004 & 2788 & 91 \\
\hline $2013-2014$ & $=-0.021 x^{2}+7.27 x+4260$ & 0.78 & $<0.001$ & 4644 & 66 \\
\hline average & - & - & - & 4534 & 78 \\
\hline
\end{tabular}

$-\mathrm{M}$, treatments without manure; $+\mathrm{M}$, treatments with manure. 


\section{Discussion}

\subsection{Manure effect on soil water variations, grain yield and WUE of winter wheat}

A previous study showed that a wheat crop requires about $480 \mathrm{~mm}$ of water for maximum yield in the Loess Plateau (Wang et al., 1994), but mean precipitation during the winter wheat growing season is only about $205 \mathrm{~mm}$ (Jin et al., 2007). This water deficit is supplied from stored soil water before winter wheat sowing. In the present study, manure amendment promoted soil water content significantly at the sowing time during 2013-2014 after two years of consecutive cultivation (Table 3). Similar results were also reported in a pea-spring wheat-potato cropping system conducted in southeastern part of the Loess Plateau (Liu et al., 2013). Increasing soil water recharge during fallow season is a crucial approach to increase soil water storage at sowing. In the present study, manure amendment improved soil water recharge by a mean of $20.7 \%$ during the fallow season throughout the experimental years, indicating more rainfall was harvested and captured in manured soil, relative to fertilized soil (Table 5). The increased rainfall harvest in manured soil was mainly due to three reasons. Firstly, the root branching and deeper rooting stimulated by manure addition left more soil to store rainfall. Secondly, manure addition enhances soil properties and then soil water transmission by improving water infiltration, saturated hydraulic conductivity, and soil water sorptivity (Khan et al., 2010). Thirdly, manured soil has higher resistance to water and winter erosion, thus reducing the water loss from soil erosion during rainy seasons. However, some studies reported a significant decrease of soil water content before winter wheat planting due to manure addition, since adding manure results in more soil water consumption during growing season of winter wheat, such that replenishment during the fallow period is insufficient to bring the soil water content back to its initial level (Huang et al., 2003; Wang et al., 2011). This phenomenon primarily due to the limited rainfall under dryland condition could not meet the water requirement of high-yielding varieties they used in the experiment.

As a result, treatments with manure produced significantly higher grain yield, and WUE than those that were not fertilized during the study. Interestingly, the increase in ET in the manure group was small (mean, 2.8\%) during 2012-2013 and 2013-2014, whereas the increase in grain yield was large (mean, 16\%), compared with that in the no-manure group (Table 6), indicating the water consumption through transpiration $(\mathrm{T})$ was promoted whereas the water loss through soil evaporation (E) was inhibited after manure application. This is consistent with the prior studies by Wang et al. (2011) and Qi et al. (2009) in a winter wheat monoculture system on the Loess plateau. Manure amendment increases crop leaf area and dry matter accumulation, then effectively promotes transpiration (Rehman et al., 2010), whereas the enlarged leaf area and canopies are effective barriers to prevent the direct effects of radiation and strong wind; thus, reducing water loss through evaporation.

\section{2. $N$ fertilization effect on soil water variations, grain yield and WUE of winter wheat}

Manure tends to recouple $\mathrm{C}$ and $\mathrm{N}$ cycles and tip soil $\mathrm{N}$ mineralization-immobilization turnover (Zhou et al., 2016), and chemical $\mathrm{N}$ fertilizer also affects decomposition rate of manure by regulating soil $\mathrm{C} / \mathrm{N}$ ratio when combined with manure (Duan et al., 2014), which alters the nutrients supply, then affects soil water uptake pattern and production of crop. In the present study, $\mathrm{N}$ fertilization caused significant decrease in soil water content after winter wheat harvest, especially at the $\mathrm{N}$ rate of $225 \mathrm{~kg} \mathrm{~N}^{-1}$ under manure 
condition (Table 3). Similarly, water deficit due to increased fertilization was also reported in semiarid regions of the central U.S. Great Plain and the Loess Plateau (Nielsen and Halvorson, 1991; Huang et al., 2003). This probably due to the larger aboveground biomass and transpirational leaf area stimulated by increased fertilizer, results in more water consumption from crop canopy during growing season (Angus and Van Herwaarden, 2001). However, Soil water recharge was improved significantly during summer fallow due to $\mathrm{N}$ fertilization, which was consistent with the results reported by Wang et al. (2012). N fertilization improved soil water recharge, either by absorbing more water during the growing season and leaving more soil reservoir to harvest rainfall during the summer fallow or by increasing the soil water holding capacity, since $\mathrm{N}$ fertilization increased root growth and biomass, thereby improving the soil organic matter content, which promotes soil water holding capacity (Deeb et al., 2016).

No significant differences in soil water recharge were noted between 75 or 150 to $300 \mathrm{~kg} \mathrm{~N} \mathrm{ha}^{-1}$, indicating that 75 or $150 \mathrm{~kg} \mathrm{~N}^{-1}$ was effective as $300 \mathrm{~kg} \mathrm{~N} \mathrm{ha}^{-1}$ in enhancing soil water recharge. Similarly, additional $\mathrm{N}$ fertilization also improved grain yield and WUE of winter wheat significantly compared with adding manure alone, but there was no further increase in grain yield or WUE when chemical $\mathrm{N}$ input $>150 \mathrm{~kg} \mathrm{~N} \mathrm{ha}^{-1}$ in most cases under manure condition.

Probably because the combined application of manure with $150 \mathrm{~kg} \mathrm{~N} \mathrm{ha}^{-1}$ results in a most efficient $\mathrm{C}: \mathrm{N}$ for the release of soil bio-immobilized $\mathrm{N}$, and enhances the synchrony between $\mathrm{N}$ supply with crop demand for $\mathrm{N}$ during the growing season, while too much $\mathrm{N}$ content in soil solution reduces root activity thus limiting nutrient uptake by crop.

\section{Conclusion}

With the population continuously increasing, the major challenge for dryland crop production is to increase crop yields with less water. The results from this 3-year study suggests manure should be involved in the fertilizer management practices, particularly under dryland condition, as a similar amount of water was consumed during winter wheat growing season, but more water was recharged during fallow season, which resulted in an improved grain yield and WUE. Comparing with applying manure alone, additional chemical $\mathrm{N}$ fertilizer input increased soil water recharge, ET, grain yield and WUE as well, but no further increases were observed when $\mathrm{N}$ rate exceeded 75 or $150 \mathrm{~kg} \mathrm{~N} \mathrm{ha}^{-1}$ in most cases. The grain yield of winter wheat varied as a polynomial function with $\mathrm{N}$ rate under manure conditions, according to the regression equation, a mean of $78 \mathrm{~kg} \mathrm{~N} \mathrm{ha}^{-1}$ is needed to achieve the $95 \%$ of highest grain yield with the presence of manure. Overall, we recommend that 78-150 $\mathrm{kg} \mathrm{N} \mathrm{ha}^{-1}$ chemical fertilizer should be combined with $30 \mathrm{t} \mathrm{ha}^{-1}$ pig manure (manure- $\mathrm{N}$ : fertilizer- $\mathrm{N}=1: 0.47$ $0.91)$ to achieve a sustainable winter wheat monoculture system in the Loess Plateau.

\section{Acknowledgements}

This study was supported by the National Key Technology Research and Development Program of the Ministry of Science and Technology of China (2015BAD23B04); the Special Scientific Research Fund of Agricultural Public Welfare Profession of China (201503124), and the Earmarked Fund for Modern Agro-industry Technology Research System (Z225020803). We sincerely thank the two corresponding authors, especially Dr. Ziyan Li , who made more contribution to the guidance in field measurements and paper writing. 


\section{References}

Angus, J.F., van Herwaarden, A.F. 2001. Increasing Water Use and Water Use Efficiency in Dryland Wheat. Agronomy Journal. 93, 290-298.

Bandyopadhyay, K.K., Misra, A.K., Ghosh, P.K., Hati, K.M. 2010. Effect of integrated use of farmyard manure and chemical fertilizers on soil physical properties and productivity of soybean. Soil \& Tillage Research. 110, 115-125.

Bao, S.D. 2000. Soil and Agricultural Chemistry Analysis. Beijing, China Agricultural Press (in Chinese).

Deeb, M., Grimaldi, M., Lerch, T.Z., Pando, A., Podwojewski, P., Bloun, M. 2016. Influence of Organic Matter Content on Hydro-Structural Properties of Constructed Technosols. Pedosphere. 26, 486-498.

Duan, Y.H., Xu, M.G., Gao, S.D., Yang, X.Y., Huang, S.M., Liu, H.B., Wang, B.R. 2014 Nitrogen use efficiency in a wheat-corn cropping system from 15 years of manure and fertilizer applications. Field Crop Research. 157, 47-56.

Efthimiadou, A., Bilalis, D., Karkanis, A., FroudWilliams, B. 2010. Combined organic/inorganic fertilization enhances soil quality and increased yield, photosynthesis and sustainability of sweet maize crop. Australian Journal of Crop Science. 4, 722-729.

Fan, T.L., Wang, S.Y., Tang, X.M., Luo, J.J., Stewart, B.A., Gao, Y.F. 2005a. Grain yield and water use in a long-term fertilization trial in Northwest China. Agricultural Water Management. 76, 36-52.

Fan, T.L., Stewart, B.A., Wang, Y., Luo, J.J, Zhou, G.Y. 2005b. Long-term fertilization effects on grain yield, water-use efficiency and soil fertility in the dryland of Loess Plateau in China. Agriculture Ecosystem and Environment. 106, 313-329.
Foster, E.J., Hansen, N., Wallenstein, M., Cotrufo, M.F. 2016. Biochar and manure amendments impact soil nutrients and microbial enzymatic activities in a semi-arid irrigated maize cropping system. Agriculture Ecosystem and Environment. 233, 404-414.

Gao, Y.J., Li ,Y., Zhang, J.C., Liu, W.G., Dang, Z.P., Cao, W.X., Qiang, Q. 2009. Effects of mulch, N fertilizer, and plant density on wheat yield, wheat nitrogen uptake, and residual soil nitrate in a dryland area of China. Nutrient Cycling in Agroecosystems. 85, 109-121.

Guo, L.Y., Wu, G.L., Li, Y., Li, C.H., Liu, W.J., Meng, J., Liu, H.T., Yu, X.F., Jiang, G.M. 2016. Effects of cattle manure compost combined with chemical fertilizer on topsoil organic matter, bulk density and earthworm activity in a wheat-maize rotation system in Eastern China. Soil \& Tillage Research. 156, 140-147.

He, Z.Q., Pagliari, H.P., Waldrip, H.M. 2016. Applied and Environmental Chemistry of Animal Manure: A Review. Pedosphere. 26, 779-816.

Huang, M.B., Dang, T.H., Gallichand, J., Goulet, M. 2003. Effect of increased fertilizer applications to wheat crop on soil-water depletion in the Loess Plateau, China. Agricultural Water Management. 58, 267-278.

Ibrahim, A., Abaidoo, R.C., Fatondji, D., Opoku, A. 2015. Hill placement of manure and fertilizer micro-dosing improves yield and water use efficiency in the Sahelian low input millet-based cropping system. Field Crops Research. 180, 29-36.

Jin, K., Cornelis, W.M., Schiettecatte, W., Lu, J.J., Yao, Y.Q., Wu, H.J., Gabriels, D., Neve, S.D., Cai, D.X., Jin, J.Y., Hartmann, R. 2007. Effects of different management practices on the soil-water balance and crop yield for improved dryland farming in the Chinese Loess Plateau. Soil \& Tillage Research. 96, 131-144. 
Ju, X.T., Xing, G.X., Chen, X.P., Zhang, S.L., Zhang, L.J., Liu, X.J., Chen, Z.L., Yin, B., Christie, P., Zhu, Z.L., Zhang, F.S. 2009. Reducing environmental risk by improving $\mathrm{N}$ management in intensive Chinese agricultural systems. PNAS. 106, 3041-3046.

Khan, N.I., Malik, A.U., Umer, F., Bodla, M.I. 2010. Effect of tillage and farm yard manure on physical properties of soil. International Journal of Plant Sciences. 1, 75-82.

Li, L.L., Li, S.T. 2014. Nitrogen mineralization from animal manures and its relation to organic $\mathrm{N}$ fractions. Journal of Integrative Agriculture. 13, 2040-2048.

Li, S.X., Wang, Z.H., Li, S.Q., Gao, Y.J. 2015. Effect of nitrogen fertilization under plastic mulched and non-plastic mulched conditions on water use by maize plants in dryland areas of China. Agricultural Water Management. 162, 15-32.

Liu, C.A., Li, F.R., Zhou, L.M., Zhang, R.H., Jia, Y., Lin, S.L., Wang, L.J., Siddique, K.H.M., Li F.M. 2013 Effect of organic manure and fertilizer on soil water and crop yields in newly-built terraces with loess soils in a semi-arid environment. Agricultural Water Management. 117, 123-132.

Nielsen, D.C., Halvorson, A.D. 1991. Nitrogen fertility influence on water stress and yield of winter wheat. Agronomy Journal. 83, 1065-1070.

Pan, F., Han, X., McLaughlin, N.B., Han, X., Li, C., Zhao, D., Zhan, L., Xu, Y. 2015. Effect of longterm fertilization on free-living nematode community structure in Mollisols. Journal of Soil Science and Plant Nutrition. 15, 129-141.

Qi, L.H., Dang, T.H., Chen, L. 2009. The water use characteristics of winter wheat and response to fertilization on dryland of Loess Plateau. Research of Soil Water Conservation. 16, 105
Rehman, S., Khalil, S., Muhammad, F., Rehman, A., Khan, A.Z., Rehman, A., Zubair, M., Khalil, I.F. 2010. Phenology, leaf area index and grain yield of rainfed wheat influenced by organic and inorganic fertilizer. Pakistan Journal of Botany. 42, 3671-3685.

Shah, G.M., Shah, G.A., Groot, J.C.J., Raza, M.A.S., Shahid, N., Lantinga, E.A. 2016. Maize nitrogen recovery and dry matter production as affected by application of solid cattle manure subjected to various storage conditions. Journal of Soil Science and Plant Nutrition. 16, 591-603.

Schoebitz, M., Vidal, G. 2016. Microbial consortium and pig slurry to improve chemical properties of degraded soil and nutrient plant uptake. Journal of Soil Science and Plant Nutrition. 16, 226-236.

Wang, J., Liu, W.Z., Dang, T.H. 2011. Responses of soil water balance and precipitation storage efficiency to increased fertilizer application in winter wheat. Plant Soil, 347, 41-51.

Wang, J., Liu, W.Z., Dang, T.H., Sainju, U.M. 2012. Nitrogen fertilization effect on soil water and wheat yield in the Chinese Loess Plateau. Agronomy Journal. 105, 143-149.

Wang, W.M. 1994. Dryland farming technology in north China. Beijing, China Agricultural Science and Technology Press, 167-192 (in Chinese).

Wu, T.Y., Schoenau, J.J., Li F.M., Qian ,P.Y., Malhi, S.S., Shi, Y.C., Xu, F.L. 2004. Influence of cultivation and fertilization on total organic carbon and carbon fractions in soils from the Loess Plateau of China. Soil \& Tillage Research. 7, 59-68. 
Yang, J., Gao, W., Ren, S.R. 2015. Long-term effects of combined application of chemical nitrogen with organic materials on crop yields, soil organic carbon and total nitrogen in fluvo-aquic soil. Soil \& Tillage Research. 151, 67-74.
Zhou, M.H., Zhu, B., Brüggemann, N., Dannenmann, M., Wang, Y.Q., Butterbach-Bahl, K. 2016. Sustaining crop productivity while reducing environmental nitrogen losses in the subtropical wheatmaize cropping systems: A comprehensive case study of nitrogen cycling and balance. Agriculture, Ecosystems and Environment. 231, 1-14. 